International Journal of Industrial Engineering Research and Development (IJIERD)

Volume 7, Issue 2, May-December 2016, pp. 63-74, Article ID: IJIERD_07_02_007

Available online at https://iaeme.com/Home/issue/IJIERD?Volume=7\&Issue $=2$

ISSN Print: 0976 - 6979 and ISSN Online: 0976 - 6987

DOI: https://doi.org/10.34218/IJIERD.7.2.2016.007

(C) IAEME Publication

\title{
OVER REACTION AND UNDERREACTION IN INDIAN STOCK MARKET: COMPARISON BASED ON ANALYSIS CONSIDERING TWO DIFFERENT SETS OF STOCKS - SHORT TERM AND LONG TERM PERSPECTIVE
}

\author{
Vineetha S Das \\ Research Scholar, Department of Mechanical Engineering, \\ College of Engineering, Trivandrum, Kerala, India
}

\section{Dr. K Krishnakumar}

Professor and Head of the Department, Department of Mechanical Engineering, College of Engineering, Trivandrum, Kerala, India

\begin{abstract}
The evidence on security returns challenges the traditional view that securities are rationally priced to reflect all publicly available information [1] and the stock prices equals the optimal forecast of it. The overconfidentinformed investor overweight the private signal relative to the public, causing the stock prices to overreact or underreact. Investor over-confidence and biased self-attribution lead to overreaction. The present paper is an empirical analysis that aims at comparing the Indian stock market situation with global markets. The paper also tries to identify the effect of the phenomena during periods prior to and after 2010 and considering both the long and short term perspective.
\end{abstract}

Key words: Behavioral finance, efficient markets, overreaction, underreaction

Cite this Article: Vineetha S Das and K Krishnakumar A. Over Reaction and Underreaction in Indian Stock Market: Comparison based on Analysis Considering Two Different Sets of Stocks - Short Term and Long Term Perspective, International Journal of Industrial Engineering Research and Development, 7(2), 2016, pp. 63-74.

https://iaeme.com/Home/issue/IJIERD?Volume=7\&Issue=2

\section{INTRODUCTION}

Contrary to the conventional belief of efficient markets, investors overreact to both good and bad news. This irrationality causes unjustifiable up and down movements in the stock prices helping investors to make irrational short-term profits. The prices 
Over Reaction and Underreaction in Indian Stock Market: Comparison based on Analysis

Considering Two Different Sets of Stocks - Short Term and Long Term Perspective

won't reflect the true value of the stock in the presence ofoverreaction and hence this will be followed by a correction. Persistent overweighting of recent information and underweighting of long-term fundamentals by irrational investors result in overreaction.

Overreaction is reported to be the reason for long term return anomalies [2]. It can be taken as prediction of behavioral finance alternative to market efficiency. The authors tried to test whether the overreaction hypothesis is predictive and the test yielded positive results. The results throw light in to the fact that overreaction is different from January effect or the seasonality in stock prices. The test also proves that looser portfolios outperform the winners and are less risky.

Ahmet Baytas and Nusret Cakicitested for overreaction hypotheses in seven industrialised countries, (US, UK, Canada, Italy, Germany, France and Japan) [3]. They found no evidence supporting overreaction in US stock market. The anomaly is significant in all other countries but the effect is week in Canada. Barberis et al. presents a model of investor sentiment, and explains how investors form beliefs [4]. The model is based on psychological evidence and produces both underreaction and overreaction for a wide range of parameter values. The strength and weight of the information affects the investment decisions and causes irrationalities such as overreaction and under reaction.

Fuzzy clustering means algorithm [5] provides evidence for the presence of over reaction in the American stock market. The results points to the fact that abnormal profits could be achieved in American stock market by adopting contrarian strategy. Daniel etal. developed a theory based on investor overconfidence and self-attribution bias. The investors reportedly overreact to private information and underreact to public information [1]. The positive return autocorrelation is shown to be a result of continuing overreaction. The misinterpretation of genuine information is reported to be the main cause of mistakes committed by investors. The approach reconciles the long term volatility with short term momentum and effectively explains event based return predictability.

Overreaction followed by, under-reaction, not equilibrium is normal in investment markets [6]. The authors suggest that these forms part of the same process. Overreaction occurs prior to portfolio formation. Evidence shows that the price reversals are not due to changes in fundamentals. It cannot be attributed to risk also. Hence the authors conclude that the overreaction of irrational investors contributes to these extreme price movements. The overconfidence theory was tested for investors having discount brokerage accounts [7]. The study shows that they trade excessively bringing their returns to a value which is substantially low even in the absence of transaction costs. The sold stocks outperform the bought ones after the transaction. This anomaly is due to overestimation of information signals.

The evidence on the stock market overreaction hypothesis $(\mathrm{ORH})$, was tested using data from 1975 to 1991 for nearly 1,000 UK companies [8]. The evidence supports the overreaction hypothesis, subject to certain qualification. The overreaction hypothesis was found acceptable within the Spanish capital market even after correcting for size when estimating excess returns [9]. Robert G Bowmana and David Iversonc examined the behavior of stock prices in New Zealand after a large weekly change in price and the findings suggested overreaction especially in the case of price declines [10].

Heng - Hsing Hsieh and Kathleen Hodnett examined the overreaction hypothesis on JSE Securities exchange [11]. The results suggest stronger mean reversal for losers 
than winners which implies more prompt correction for losers than winners. The authors attribute this asymmetry to behavioral biases. Padma Kadiyala and $\mathrm{P}$ Raghavendra Rau reports that the investors under-react to prior information as well as the information conveyed by the event [12].

Dr. Mayank Joshipura provides strong evidence for short term momentum and long term contrarian profits [13]. The work proves that market overreaction followed by initial underreaction results in contrarian profits. Vanita Tripathi and Shalini Aggerwal revealed the presence of statistically significant but asymmetric overreaction in Indian stock market considering overreaction in a long term perspective [14].

Studies on overreaction in stock market is reported from most of the developed and developing counties, Russia [15], UK [16], [17], Brazil [18], Malaysia [19], Turkey [20], US [21], China [22]-[24] are a few to cite. These works pertains to different periods. Most of the works followed the system introduced by DeBondt and Thaler [2] but some used other tools also. Majority of the works used the cumulative average abnormal returns to evaluate the performance, while a few works challenged the system and reported that holding period returns would be a better proxy for performance.

The present study analyses the overreaction effect in Indian stock market over the period from January 2005 to December 2014. The paper aims to unearth the overreaction effect over different time horizons. The changes in empirical results, due to the use of different sets of stocks for analysis is also dealt with.

\section{DATA AND METHODOLOGY}

The data relating to the returns of CNX Nifty total return index stocks and CNX 500 index stocks for the period from January 2005 to December 2014 taken as available from Prowess database and is used for analysis of overreaction during the period. The index return for both the indices during the period is also obtained from the same source. Based on the data available for the selected analysis period, the CNX total return index stocks consisted of 42 stocks (Set I) and the CNX 500 index stocks consisted of 323 stocks (Set II). The two sets were identified considering the availability of monthly return data for theperiod from January 2005 to December 2014. The abnormal return (market adjusted) $(A R)$ for the individual stocks were calculated in comparison with the index return as follows for both the sets of stocks:

$$
A R t i=R t i-R m t
$$

Where

$$
\begin{gathered}
A R t i=\text { The abnormal return on stock } i \text { at time } t \\
\text { Rti }=\text { Return on individual stock } i \text { at time } t
\end{gathered}
$$

and

$$
R m t=\text { Return on market portfolio at time } t
$$

$R m t$ for the first set is the monthly return on the total return index and the second, the return on the CNX 500 index. The cumulative abnormal return (CARi) is calculated for individual stocks belonging to both the sets for different formation periods ranging from a year to 5 years. 
Over Reaction and Underreaction in Indian Stock Market: Comparison based on Analysis

Considering Two Different Sets of Stocks - Short Term and Long Term Perspective

$$
C A R i=\sum_{t=-k}^{0} A R t i
$$

Where, $k$ is the duration of the formation and test periods. Winner and loser clusters were identified for the selected stocks based on their cumulative abnormal returns during the formation period of one year, two years, three years and five years. For the first set of stocks considered for analysis the winner clusters consisted of 5 stocks having the highest cumulative abnormal return during the respective formation period and the worst performing 5 stocks constitute the loser cluster. Similarly the winner cluster for the second set consisted of the best performing 35 stocks while the least performing 35 stocks forms the loser cluster.

After identifying the clusters, the average abnormal $(A A R)$ return is calculated for each month during the test period for both winner and loser portfolios

$$
A R R p=\sum_{0}^{k} A R i
$$

Where, $p$ represents the winner or the loser portfolio.

$$
\begin{aligned}
& p=W \text { for winner cluster } \\
& p=L \text { for the loser cluster }
\end{aligned}
$$

From the average abnormal return cumulative average abnormal return (CAAR) and mean cumulative average abnormal return $(M C A A R)$ are calculated for both winner and loser portfolios during the respective test periods.

$$
\text { CAARp }=\sum_{t=1}^{k} A A R t
$$

Where, $\mathrm{k}$ is the length of the test period (12 months, 24 months, 36 months or 60 months).

$$
\operatorname{MCAARp}=\frac{1}{k} \sum_{i=1}^{k} \text { CAARp it }
$$

MCAARp indicates how much cumulated excess returns stocks in the portfolio, $p$ (winner or loser) earns on average during the test period. Significant difference between MCAARp of winner and loser portfolios points to the presence of market inefficiency. When the market is efficient

$$
M C A A R_{W}=M C A A R_{L}
$$

The null hypothesis for testing whether the market is efficient is given by

$$
M C A A R_{W}-M C A A R_{L}>0
$$

Relevant $\mathrm{t}$ statistic is found out for each of the $\mathrm{k}$ post formation months. In order to test the presence of any statistically significant difference in investment performance, pooled estimator of population variance $\left(S_{t}^{2}\right)$ is calculated.

$$
S t^{2}=\frac{\left[\sum_{i=1}^{k}\left(C A A R_{W}-M C A A R_{W, t}\right)^{2}+\sum_{i=1}^{k}\left(C A A R_{L}-M C A A R_{L, t}\right)^{2}\right]}{2(K-1)}
$$


$K$ is the sample size of two samples and hence the difference of sample means equals $2 S t^{2} / K$ and the $t$ statistic $\left(T_{t}\right)$ is therefore

$$
T_{t}=\left(M C A A R_{L}, t-M C A A R_{w}, t\right) / \sqrt{\left(2 S_{t}^{2} / K\right)}
$$

\section{RESULTS AND DISCUSSION}

As per the literature markets may be considered efficient for shorter investment horizons. Overreaction effect is not prominent during periods of six months and one year. This is attributed to short term price pressure and lack of liquidity [25], [26]. The empirical results of the present study give information on the return trends and the effect of overreaction in Indian security market.

For short horizon of a year formation and test periods, inefficiency is significant throughout the year 2008 and first six months of the test period (2014) in Indian stock market for the first set of stocks.

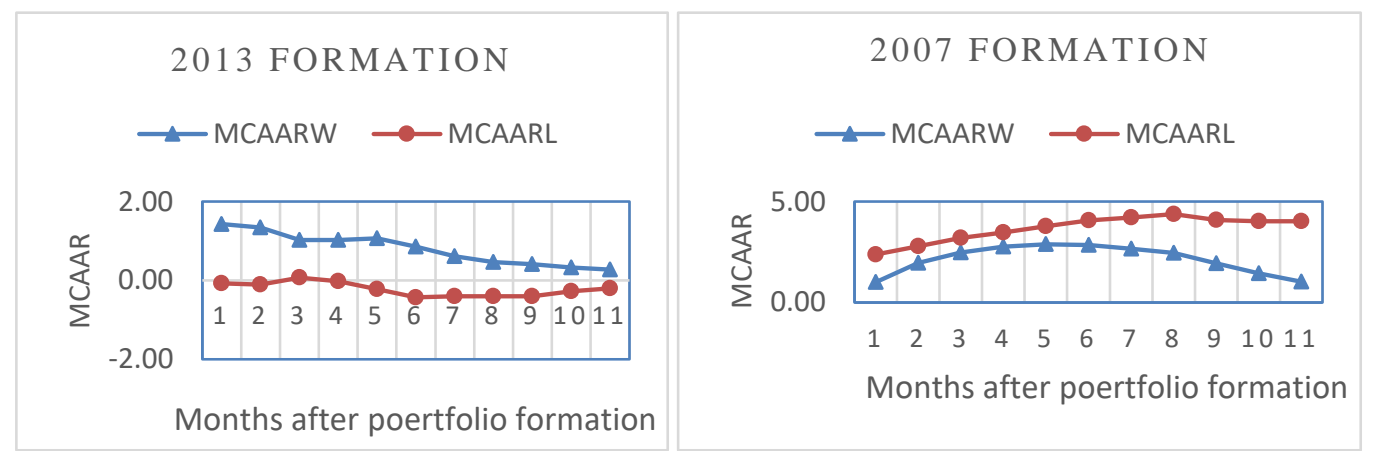

Figure 1 Return trend after one year formation period - set I

Table 1 MCAAR $_{\mathrm{W}}$ MCAAR $_{\mathrm{L}}$ and $\mathrm{t}$ Statistic for 1 year formation and test periods - Set I

\begin{tabular}{|c|c|c|c|c|c|c|c|}
\hline \multicolumn{4}{|c|}{$\mathbf{2 0 1 3}$ formation } & \multicolumn{5}{c|}{$\mathbf{2 0 0 7}$ formation } \\
\hline $\begin{array}{c}\text { Month \& } \\
\text { Year }\end{array}$ & MCAAR $_{\mathbf{W}}$ & MCAAR $_{\mathbf{L}}$ & $\mathbf{T}_{\mathbf{t}}$ & $\begin{array}{c}\text { Month \& } \\
\text { Year }\end{array}$ & MCAAR $_{\mathbf{W}}$ & MCAAR $_{\mathbf{L}}$ & $\mathbf{T}_{\mathbf{t}}$ \\
\hline Feb-14 & 1.428 & -0.075 & -8.721 & Feb-08 & 1.008 & 2.380 & -8.212 \\
\hline Mar-14 & 1.343 & -0.102 & -8.191 & Mar-08 & 1.958 & 2.776 & -4.566 \\
\hline Apr-14 & 1.029 & 0.070 & -3.314 & Apr-08 & 2.485 & 3.208 & -4.063 \\
\hline May-14 & 1.020 & -0.020 & -3.473 & May-08 & 2.757 & 3.475 & -5.407 \\
\hline Jun-14 & 1.064 & -0.218 & -3.473 & Jun-08 & 2.882 & 3.778 & -6.286 \\
\hline Jul-14 & 0.858 & -0.429 & -2.438 & Jul-08 & 2.851 & 4.062 & -8.110 \\
\hline Aug-14 & 0.609 & -0.402 & -1.563 & Aug-08 & 2.671 & 4.209 & - \\
\hline Sep-14 & 0.465 & -0.403 & -1.255 & Sep-08 & 2.447 & 4.378 & -9.893 \\
\hline Oct-14 & 0.406 & -0.407 & -1.160 & Oct-08 & 1.930 & 4.092 & -4.667 \\
\hline Nov-14 & 0.323 & -0.279 & -0.780 & Nov-08 & 1.437 & 4.021 & -5.966 \\
\hline Dec-14 & 0.274 & -0.199 & -0.589 & Dec-08 & 1.039 & 4.030 & -7.843 \\
\hline
\end{tabular}

During the 2008 test period, the winner portfolio shows an uptrend in the first half and then decreases, while the losers exhibit a clear trend of contrarian profits (Figure 1). During 2014 the contrarian effect is prominent for winner portfolio compared to the loser ones. The results given in following table clearly deviate from the popular findings. 
Over Reaction and Underreaction in Indian Stock Market: Comparison based on Analysis

Considering Two Different Sets of Stocks - Short Term and Long Term Perspective

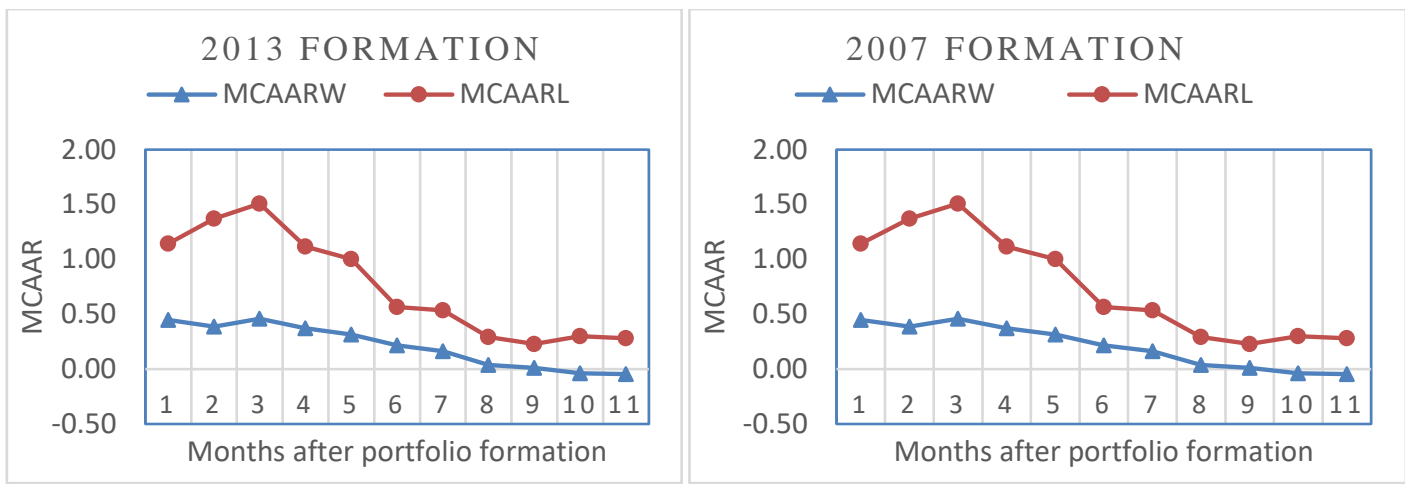

Figure 2 Return trend after one year formation period - set II

For the set II stocks MCAAR of winners remains positive for the test period though there is a declining trend (Figure 2). There is no significant chance for contrarian effect within a period of one year. Though there is reversal of sign of MCAAR of loser portfolio, the effect is not significant enough to support the possibility of achieving excess returns by adopting contrarian strategy and this confirms the findings of previous literature.

Table 2 MCAAR $_{\mathrm{W}}, \mathrm{MCAAR}_{\mathrm{L}}$ and $\mathrm{t}$ Statistic for 1 year formation and test periods Set II

\begin{tabular}{|c|c|c|c|c|c|c|c|}
\hline \multicolumn{4}{|c|}{$\mathbf{2 0 1 3}$ formation } & \multicolumn{4}{c|}{$\mathbf{2 0 0 7}$ formation } \\
\hline $\begin{array}{c}\text { Month \& } \\
\text { Year }\end{array}$ & MCAAR $_{\mathbf{W}}$ & MCAAR $_{\mathbf{L}}$ & $\mathbf{T}_{\mathbf{t}}$ & $\begin{array}{c}\text { Month \& } \\
\text { Year }\end{array}$ & MCAAR $_{\mathbf{W}}$ & MCAAR $_{\mathbf{L}}$ & $\mathbf{T}_{\mathbf{t}}$ \\
\hline Feb-14 & 3.023 & 0.995 & -8.338 & Feb-08 & 0.448 & 1.142 & 0.720 \\
\hline Mar-14 & 1.802 & -0.367 & -2.655 & Mar-08 & 0.389 & 1.372 & 0.998 \\
\hline Apr-14 & 1.752 & 0.186 & -1.758 & Apr-08 & 0.459 & 1.508 & 1.034 \\
\hline May-14 & 1.480 & -0.255 & -1.745 & May-08 & 0.370 & 1.117 & 0.673 \\
\hline
\end{tabular}

For two years of formation and teat periods the winner portfolio of the first set of stocks has a down trend during the test period 2013 -14 (2011 - 12 formation), while it drops first and the increases during the other test period. The loser portfolio continues its declining trend during both the test periods though the intensity is less significant in the second period (Figure 3). After an initial period of overreaction the stock prices returns to the fundamental values and hence the anomaly and the chance of abnormal return disappears.

Considering MCAARw, MCAAR $\mathrm{M}_{\mathrm{W}}$ and $\mathrm{t}$ Statistic for 2 year formation and test periods for the first set of stocks, the anomaly is evident only in the first few months of the test periods. For the CNX 500 stocks (set II) the anomaly is evident for about 12 months after the portfolio formation period, $2011-12$ and then it gradually disappears. But after the portfolio formation period, 2005 - 06 the anomaly was significant only for 4 months (table 3 ). 

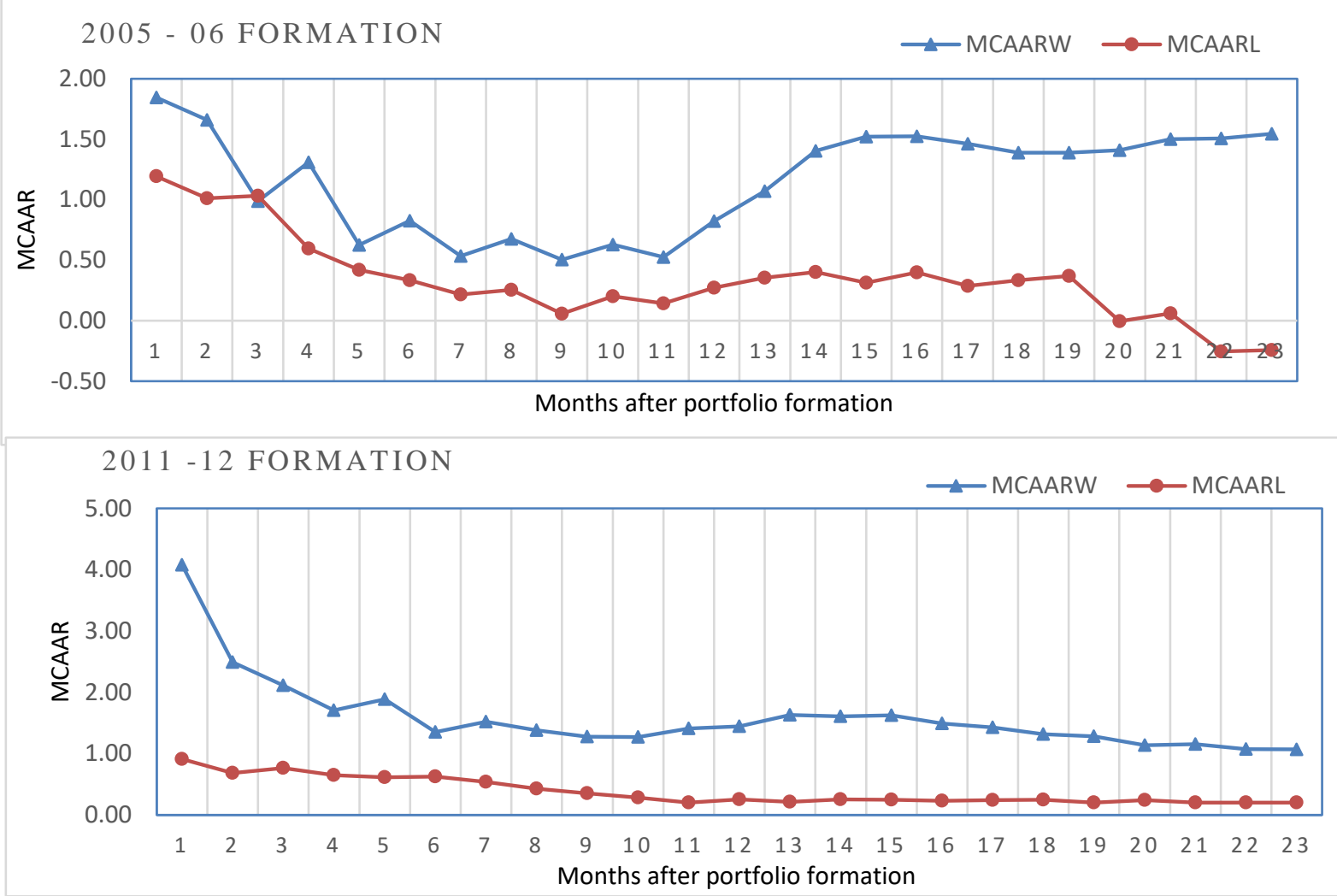

Figure 3 Return trend after 2 year formation period - set I

Table 3 MCAAR $_{\mathrm{W}}$, MCAAR $_{\mathrm{L}}$ and $\mathrm{t}$ Statistic for 2 year formation and test periods - Set II

\begin{tabular}{|c|c|c|c|c|c|c|c|}
\hline \multicolumn{3}{|c|}{$\mathbf{2 0 1 1}-\mathbf{1 2}$ formation } & \multicolumn{4}{|c|}{$\mathbf{2 0 0 5}$-06 formation } \\
\hline $\begin{array}{c}\text { Month \& } \\
\text { Year }\end{array}$ & MCAAR $_{W}$ & MCAAR $_{\mathbf{L}}$ & $\mathbf{T}_{\mathbf{t}}$ & $\begin{array}{c}\text { Month } \\
\text { \& Year }\end{array}$ & MCAAR $_{\mathbf{W}}$ & MCAAR $_{\mathbf{L}}$ & $\mathbf{T}_{\mathbf{t}}$ \\
\hline Feb-13 & 1.242 & 0.213 & -15.762 & Feb-07 & 0.271 & -0.251 & -11.656 \\
\hline Mar-13 & 0.585 & -0.230 & -3.358 & Mar-07 & 0.298 & 0.042 & -2.618 \\
\hline Apr-13 & 0.905 & -0.142 & -3.690 & Apr-07 & 0.245 & -0.008 & -2.464 \\
\hline May-13 & 0.846 & -0.320 & -3.830 & May-07 & 0.293 & -0.034 & -3.036 \\
\hline Jun-13 & 0.920 & -0.447 & -4.231 & Jun-07 & 0.093 & -0.139 & -1.171 \\
\hline Jul-13 & 0.815 & -0.560 & -3.917 & Jul-07 & -0.037 & -0.078 & -0.177 \\
\hline Aug-13 & 0.850 & -0.559 & -3.994 & Aug-07 & -0.014 & -0.160 & -0.579 \\
\hline Sep-13 & 0.892 & -0.588 & -4.135 & Sep-07 & -0.038 & -0.001 & 0.118 \\
\hline Oct-13 & 0.854 & -0.415 & -2.965 & Oct-07 & 0.014 & -0.106 & -0.341 \\
\hline Nov-13 & 0.993 & -0.380 & -2.877 & Nov-07 & 0.135 & 0.217 & 0.133 \\
\hline Dec-13 & 0.994 & -0.296 & -2.600 & Dec-07 & 0.171 & 0.255 & 0.136 \\
\hline Jan-14 & 0.997 & -0.321 & -2.645 & Jan-08 & 0.320 & 0.426 & 0.143 \\
\hline Feb-14 & 1.049 & -0.224 & -2.352 & Feb-08 & 0.489 & 0.682 & 0.205 \\
\hline Mar-14 & 0.969 & -0.303 & -2.162 & Mar-08 & 0.541 & 0.673 & 0.139 \\
\hline Apr-14 & 0.927 & -0.213 & -1.814 & Apr-08 & 0.690 & 0.707 & 0.017 \\
\hline May-14 & 0.885 & -0.229 & -1.748 & May-08 & 0.627 & 0.638 & 0.011 \\
\hline Jun-14 & 0.867 & -0.141 & -1.493 & Jun-08 & 0.657 & 0.533 & -0.116 \\
\hline
\end{tabular}


Over Reaction and Underreaction in Indian Stock Market: Comparison based on Analysis

Considering Two Different Sets of Stocks - Short Term and Long Term Perspective

For the first half of 2007(first year after portfolio formation) the winner portfolio shows a slight down trend. Then there is a positive shift in return for the next few months and then again there is a down trend (table 3). Though there is no significant uptrend for the losers during 2007, there is a positive hike towards the end of the year which subsequently reverses towards the middle of 2008. During the 2013 - 14 test period both winners and losers suffer a slight down trend in returns for initial months and then it is stable till the end of the test period.

When three years of formation and test periods are considered (for Set I Stocks), the anomaly is significant just after the formation period. During the first half of 2008 there is statistically significant evidence to support the overreaction in Indian stock market (table 4). The winners during the portfolio formation period suffer remarkable loss during the test period, which confirms the findings in of the previous works (Figure 4). But the losers show considerable momentum. The declining trends prolong during the first year of the test period for the losers, and then show a reversal which is not as significant as the declining trend shown by the winners.For the second test period $(2012-14)$ the anomaly is evident only during the first few months of the test period (table 4). After a slight disturbance during the first few months the winner portfolio keeps stable during the test period. The losers during the formation period show a brilliant come back during the first year of the test period, then suffers decline in the second year and then stabilizes (Figure 4).

Table 4 MCAAR $_{\mathrm{W}}, \mathrm{MCAAR}_{\mathrm{L}}$ and $\mathrm{t}$ Statistic for 3 year formation and test periods Set I

\begin{tabular}{|l|l|l|l|l|l|l|c|}
\hline \multicolumn{3}{|l|}{2005 - 2007 formation } & \multicolumn{3}{c|}{2009 - 2011 formation } \\
\hline $\begin{array}{c}\text { Month \& } \\
\text { Year }\end{array}$ & MCAAR $_{\mathbf{W}}$ & MCAAR $_{\mathbf{L}}$ & $\mathbf{T}_{\mathbf{t}}$ & $\begin{array}{c}\text { Month } \\
\text { \& Year }\end{array}$ & MCAAR $_{\mathbf{W}}$ & MCAAR $_{\mathbf{L}}$ & $\mathbf{T}_{\mathbf{t}}$ \\
\hline Feb-08 & 3.186 & 2.636 & -3.730 & Jun-08 & 2.288 & 0.369 & -2.859 \\
\hline Mar-08 & 3.540 & 2.282 & -6.625 & Jul-08 & 1.929 & 0.169 & -2.401 \\
\hline Apr-08 & 3.343 & 1.257 & -4.968 & Aug-08 & 1.604 & 0.105 & -1.913 \\
\hline May-08 & 2.790 & 0.806 & -3.670 & Sep-08 & 1.283 & -0.358 & -1.725 \\
\hline
\end{tabular}

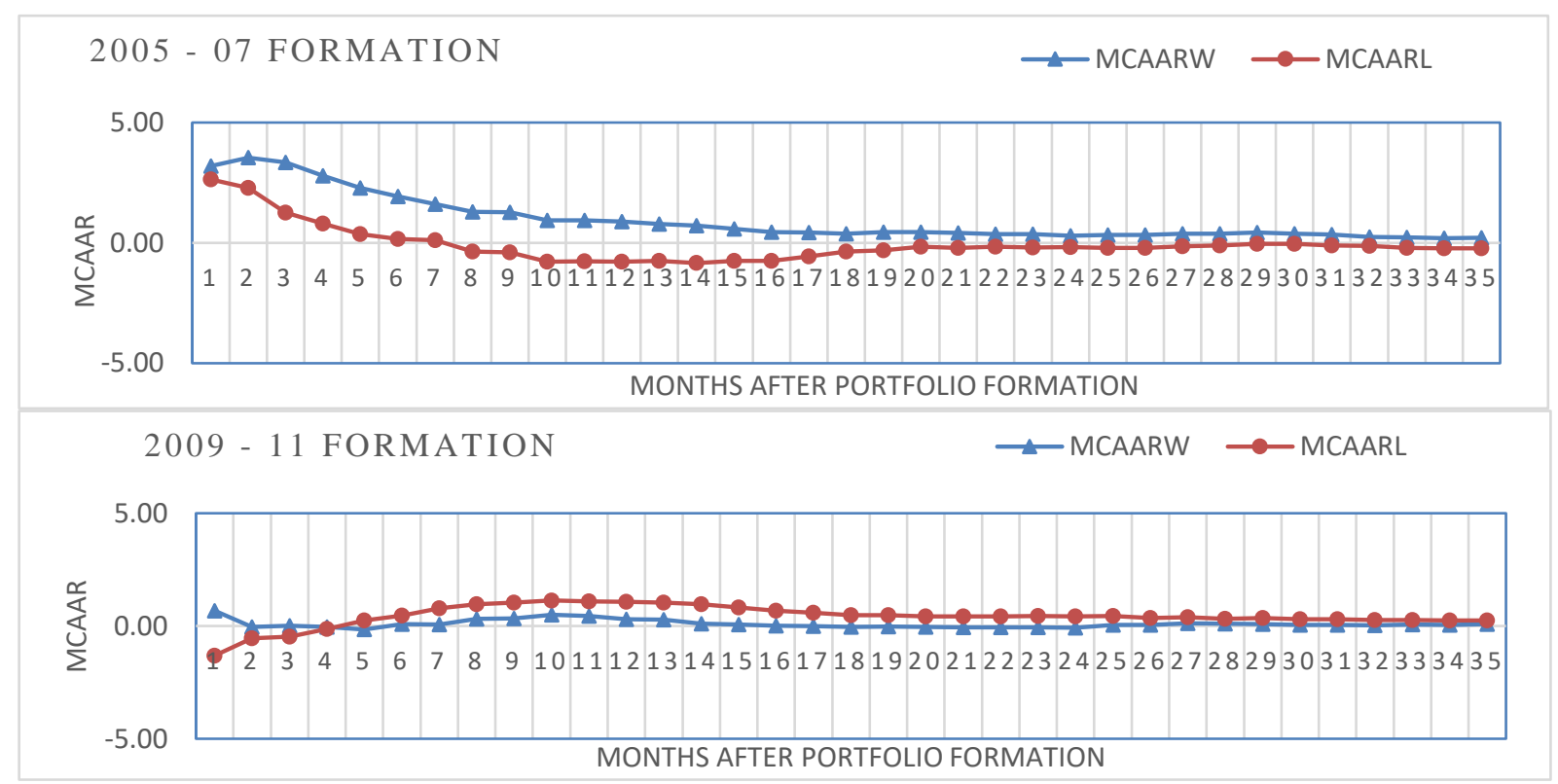

Figure 4Return trend after 3 year formation period - set I 


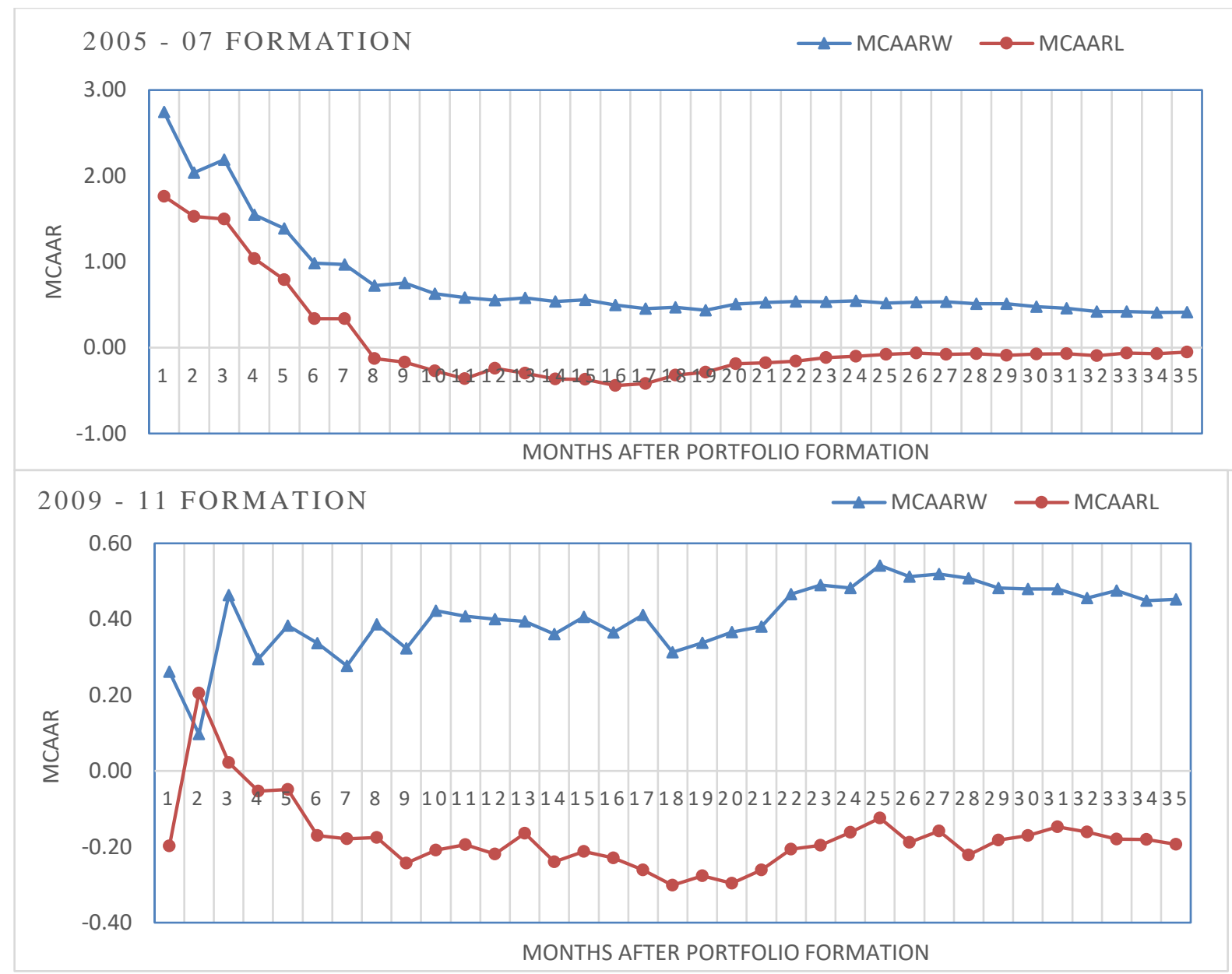

Figure 5 Return trend after 3 year formation period - set II

For the five year formation and test periods the return trend is as follows:

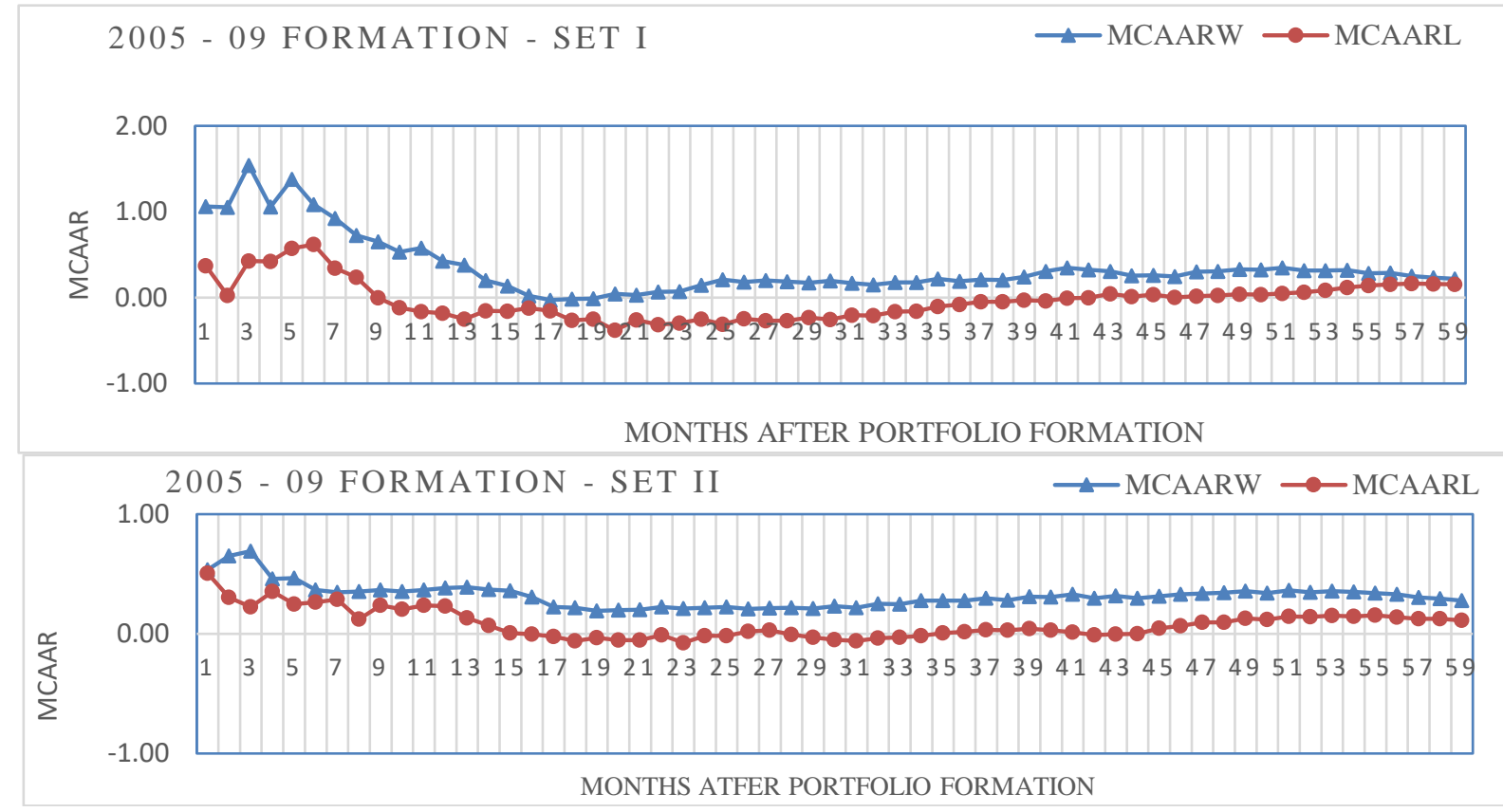

Figure 6 Return trend after 5 year formation period - set I \& Set II 
Over Reaction and Underreaction in Indian Stock Market: Comparison based on Analysis

Considering Two Different Sets of Stocks - Short Term and Long Term Perspective

After five years formation period the return trend is similar for both the set of stocks. The existence of the anomaly is statistically significant only for first few months of the test period for both the sets of stocks. Both the winner and the loser portfolio have a declining trend during the initial phase of the test period, which is more prominent for the winners (Figure 6).

Table 5 MCAAR $_{\mathrm{W}}$ MCAAR $_{\mathrm{L}}$ and $\mathrm{t}$ Statistic for 5 year formation and test periods - Set I

\begin{tabular}{|c|c|c|c|c|c|c|c|}
\hline \multicolumn{8}{|c|}{2005 - 2009 formation } \\
\hline $\begin{array}{l}\text { Month \& } \\
\text { Year }\end{array}$ & MCAAR $_{W}$ & $\mathbf{M C A A R}_{\mathbf{L}}$ & $\mathbf{T}_{\mathbf{t}}$ & $\begin{array}{l}\text { Month \& } \\
\text { Year }\end{array}$ & MCAAR $_{W}$ & $\operatorname{MCAAR}_{\mathrm{L}}$ & $\mathbf{T}_{\mathbf{t}}$ \\
\hline Feb-10 & 1.059 & 0.369 & $\begin{array}{l}- \\
19.755 \\
\end{array}$ & May-10 & 1.058 & 0.421 & $\begin{array}{l}- \\
2.451\end{array}$ \\
\hline Mar-10 & 1.052 & 0.024 & - & Jun-10 & 1.378 & 0.574 & - \\
\hline Apr-10 & 1.542 & 0.425 & -5.901 & Jul-10 & 1.084 & 0.618 & - \\
\hline
\end{tabular}

Classification of winner and loser clusters will be more genuine when the duration of formation period is more. The winner portfolio of both the sets shows a declining trend during the initial periods and then stabilizes. For the losers, there is an initial reversal in return and then stabilizes. The winners have a better return performance compared to the losers during the whole of the test period.

Table $6 \mathrm{MCAAR}_{\mathrm{W}}, \mathrm{MCAAR}_{\mathrm{L}}$ and $\mathrm{t}$ Statistic for 5 year formation and test periods - Set II

\begin{tabular}{|c|c|c|c|c|c|c|c|}
\hline \multicolumn{7}{|c|}{$2005-2009$ formation } \\
\hline $\begin{array}{c}\text { Month \& } \\
\text { Year }\end{array}$ & MCAAR $_{\mathbf{W}}$ & MCAAR $_{\mathbf{L}}$ & $\mathbf{T}_{\mathbf{t}}$ & $\begin{array}{c}\text { Month \& } \\
\text { Year }\end{array}$ & MCAAR $_{\mathbf{W}}$ & MCAAR $_{\mathbf{L}}$ & $\mathbf{T}_{\mathbf{t}}$ \\
\hline Feb-10 & 0.534 & 0.507 & -0.970 & May-10 & 0.460 & 0.355 & -0.924 \\
\hline Mar-10 & 0.651 & 0.304 & -6.765 & Jun-10 & 0.467 & 0.247 & -1.778 \\
\hline Apr-10 & 0.692 & 0.225 & -8.209 & Jul-10 & 0.365 & 0.264 & -0.745 \\
\hline
\end{tabular}

\section{CONCLUSIONS}

Global evidence on stock market anomalies points towards short term efficiency and long term inefficiency of stock markets. Short term price pressure and lack of liquidity are the said reason for reduced inefficiencies during the short run, while behavioral biases contribute to inefficiency in the long run. Though this is the rule, political, social and global factors may cause empirical evidence to prove otherwise.

- Empirical findings on total return index stocks suggests market anomaly during 2008 but not during 2014.

- The anomaly is not significant for both the periods when CNX 500 stocks were analysed.

- For two and three years of formation and test periods, the anomaly is more significant during the test periods before and after 2010 for both the sets of stocks. Significant overreaction effect is present only during the first phase of the test period.

- With three years of formation and test periods, the anomaly is significant just after the formation period. The behavior is almost similar for both the sets of stocksduring the first test period. 
- The winners during the portfolio formation period suffer remarkable loss during the test period, while the losers show considerable momentum.

- After a slight disturbance during the first few months the winner portfolio keeps stable during the second test period for the set I stocks. The losers show a brilliant come back during the first year of the test period, then suffers a slight decline in the second year and then stabilizes

- A significant disturbance during the initial months of the test period followed by a stable performance is witnessed for both winners and losers of the set II stocks.

- The empirical evidence shows the behavior of the market changes with time.

- When a very long duration of formation period is considered, the anomaly is found to exist only for a very few months in the initial phase of the test period. The clustering of stocks into winners and losers will be based on the long term performance and fundamental value of the stocks. This reduces the chances for predictable mispricing during the five year formation and test periods.

\section{REFERENCES}

[1] K. Daniel, D. Hirshleifer, and A. Subrahmanyam, "Investor Psychology and Security Market Under- and Overreactions," J. Finance, vol. LIII, no. 6, pp. 1839-1885, 1998.

[2] W. F. M. De Bondt and R. Thaler, "Does the Stock Market Overreact?," J. Finance, vol. 40, no. 3, pp. 793-805, 1985.

[3] A. Baytas and N. Cakici, "Do markets overreact: International evidence," J. Bank. Financ., vol. 23, no. 7, pp. 1121-1144, 1999.

[4] N. Barberis, A. Shleifer, and R. Vishny, "A model of investor sentiment," $J$. financ. econ., vol. 49, pp. 307-343, 1998.

[5] R. A. Aguiar, R. M. Sales, and S. Paulo, "Fuzzy Clustering Means Algorithm," 978-1-4244-6928-4/10, pp. 376-380, 2010.

[6] D. N. Dreman and E. a. Lufkin, "Investor Overreaction: Evidence That Its Basis Is Psychological," J. Psychol. Financ. Mark., vol. 1, no. 1, pp. 61-75, 2000.

[7] T. O. Odean, "Do Investors Trade Too Much ?," Am. Econ. Rev., pp. 1279-1298, 1999.

[8] G. Dissanaike, "On the computation of returns in tests of the stock market overreaction hypothesis," J. Bank. Financ., vol. 18, no. 6, pp. 1083-1094, 1994.

[9] A. A. and G. Rubio, "Overreaction in the Spanish Equity Market," J. Bank. Financ., vol. 14, pp. 469-481, 1990.

[10] R. G. Bowman and D. Iverson, "Short-run overreaction in the New Zealand stock market," Pacific-Basin Financ. J., vol. 6, no. 5, pp. 475-491, 1998.

[11] H. Hsieh and K. Hodnett, "Tests of the Overreaction Hypothesis and the Timing of Mean Reversals on the JSE Securities Exchange ( JSE ): the Case of South Africa," J. Appl. Financ. Bank., vol. 1, no. 1, pp. 107-130, 2011.

[12] P. R. R. Padma Kadiyala and Au, "Investor Reaction to Corporate Event Announcements: Under - reaction or Over - reaction," J. Bussiness, no. May, 2002.

[13] D. M. Joshipura, "Does the stock market overreact? Empirical evidence of contrarian returns from Indian markets," 2012.

[14] V. Tripathi, "Overreaction Effect in Indian Stock Market," no. 1, 2009.

[15] N. Abrosimova, G. Dissanaike, and D. Linowski, "Testing weak-form efficiency of the Russian stock market," EFA 2002 Berlin Meet. Present. Pap., pp. 0-26, 2002. 
Over Reaction and Underreaction in Indian Stock Market: Comparison based on Analysis

Considering Two Different Sets of Stocks - Short Term and Long Term Perspective

[16] A. Pepelas, "Testing the Overreaction Hypothesis in the UK Stock Market by using Inter \& Intra Industry Contrarian Strategies," 2008.

[17] S. Spyrou, K. Kassimatis, and E. Galariotis, "Short-term overreaction, underreaction and efficient reaction: evidence from the London Stock Exchange," Appl. Financ. Econ., vol. 17, no. 3, pp. 221-235, 2007.

[18] N. C. A. Costa Jr., "Overreaction in the Brazilian stock market," J. Bank. Financ., vol. 18, pp. 633-642, 1994.

[19] R. Ali, Z. Ahmad, and S. V. Anusakumar, "Stock market overreaction and trading volume: Evidence from Malaysia," Asian Acad. Manag. J. Account. Financ., vol. 7, no. 2, pp. 103-119, 2011.

[20] G. Vardar and B. Okan, "Short Term Overreaction Effect: Evidence on the Turkish Stock Market," Int. Conf. Emerg. Econ. Issues a Glob. World, pp. 155$165,2008$.

[21] J. Michel, "Stock Market Overreaction to Management Earnings Forecasts," vol. 2014, no. March, pp. 1-51, 2014.

[22] Y. Wu, "Momentum trading, mean reversal and overreaction in Chinese stock market," Rev. Quant. Financ. Account., vol. 37, no. 3, pp. 301-323, 2011.

[23] H. Lin, S. Zi-Jun, L. Xiu-Yi, and C. Wen-Jun, "An Empirical Study on the Overreaction of Shanghai Stock Market," Chinese Stud., vol. 02, no. 01, pp. 3235, 2013.

[24] Y. Fang, "Empirical Study on Overreaction and Underreaction in Chinese Stock Market Based on ANAR-TGARCH Model," J. Financ. Risk Manag., vol. 2, no. 4, pp. 71-76, 2013.

[25] N. Jegadeesh, "Evidence of predictable behavior of security returns," The Journal of Finance, vol. 45, no. 3. pp. 881-898, 1990.

[26] B. N. Lehmann, "Fads, Mar tingales and Market Efficiency," Q. J. Econ., vol. 105, no. 1, pp. 1-28, 1990.

[27] Sindhu, K. P., Dr. Kalidas, M. G. and Anil Chandran. S. A Study on Factors Influencing Investor Sentiment in Indian Stock Market, International Journal of Management (IJM), 5(1), 2014, pp. 7-13.

[28] B. A. Prajapati, Ashwin Modi and Jay Desai. A Survey of Day of the Month Effect in World Stock Markets, International Journal of Management (IJM), 4(1), 2013, pp. 221-234. 